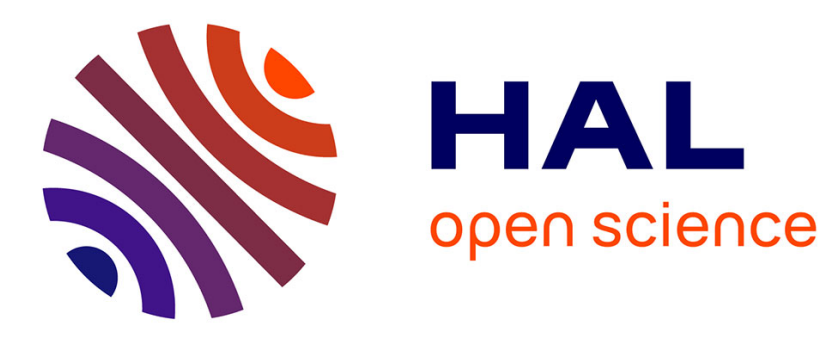

\title{
New insights into the chemical composition of chitinozoans
}

Jérémy Jacob, Florentin Paris, Olivier Monod, Meller A. Miller, Peng Tang, Simon C. George, Jean-Michel Bény

\section{- To cite this version:}

Jérémy Jacob, Florentin Paris, Olivier Monod, Meller A. Miller, Peng Tang, et al.. New insights into the chemical composition of chitinozoans. Organic Geochemistry, 2007, 38 (10), pp.1782-1788. 10.1016/j.orggeochem.2007.06.005 . insu-00149308

\section{HAL Id: insu-00149308 \\ https://hal-insu.archives-ouvertes.fr/insu-00149308}

Submitted on 25 May 2007

HAL is a multi-disciplinary open access archive for the deposit and dissemination of scientific research documents, whether they are published or not. The documents may come from teaching and research institutions in France or abroad, or from public or private research centers.
L'archive ouverte pluridisciplinaire HAL, est destinée au dépôt et à la diffusion de documents scientifiques de niveau recherche, publiés ou non, émanant des établissements d'enseignement et de recherche français ou étrangers, des laboratoires publics ou privés.

\section{(ㅇ)(1) $\$$}

Distributed under a Creative Commons Attribution - NonCommercial - NoDerivatives 44.0 


\title{
New insights into the che mical composition of chitinozoans
}

Jérémy Jacob ${ }^{1, *}$, Florentin Paris ${ }^{2}$, Olivier Monod ${ }^{1}$, Merrell A. Miller ${ }^{3}$, Peng Tang ${ }^{2}$, Simon C. George ${ }^{4}$ and Jean-Michel Bény ${ }^{1}$.

${ }^{1}$ ISTO - UMR 6113 CNRS - Université d’Orléans, Bâtiment Géosciences, 45067 Orléans Cedex 2, France.

${ }^{2}$ Géosciences-Rennes, UMR 6118 du CNRS, 35042 Rennes-cedex, France.

${ }^{3}$ Saudi Arabian Oil Company, Dhahran, Saudi Arabia 31311.

${ }^{4}$ Australian Centre for Astrobiology, Macquarie University, NSW 2109, Australia.

\begin{abstract}
The chemical structure of isolated chitinozoan specimens extracted from Early Silurian marine rocks has been investigated by micro-FTIR, laser micro-Raman spectroscopy and laser micropyrolysis-gas chromatography/mass spectrometry (LmPyGC/MS). The samples were subjected to relatively low thermal stress as attested by several indices. LmPy-GC/MS and micro-FTIR indicate that chitinozoans consist mostly of a kerogen network dominated by aromatic groups with a low contribution of aliphatics and oxygen- or nitrogen-bearing compounds. No chitin-related product was found in the pyrolysate of the chitinozoans, confirming previous findings on the occurrence of this biopolymer in the fossil record.
\end{abstract}

Keywords: Chitinozoans, Laser micropyrolysis-GC/MS, chitin, Lower Palaeozoic

\footnotetext{
*Corresponding author: jeremy.jacob@univ-orleans.fr
} 


\section{Introduction}

Chitinozoans are small organic-walled microfossils characteristic of Lower Palaeozoic marine rocks that can occur as single vesicles or in chains of connected vesicles (e.g., Paris et al., 1999). Although these microfossils have been studied for several decades and are of undisputed stratigraphic utility (e.g., Paris, 1996), their biological affinities remain controversial (see discussion in Miller, 1996). A classical hypothesis relates chitinozoans to the egg-cases of unknown Metazoa (e.g., Paris and Nõlvak, 1999 and references therein). The chemical structure of chitinozoans is still uncertain, but once established might be helpful in determining the biological affinities of these enigmatic fossils. Chitinozoans were named by Eisenack (1931), who demonstrated their resistance to concentrated acids and bases. After enzymatic degradation performed on specimens of Cyathochitina sp., Voss-Foucart and Jeuniaux (1972) could not detect N-acetyl D-glucosamine, which excluded the presence of chitin in their samples. Whether this was the result of diagenetic degradation of chitin, or the lack of chitin in the original organisms remained to be elucidated. More recent work has shown that the degradation of chitin tissues occurs during early diagenesis (Baas et al., 1995). The oldest evidence for chitin in fossil materials dates back to the Cretaceous and Tertiary (Brumioul and Voss-Foucart, 1977; Stankiewicz et al., 1997a, 1997b). Pyrolysis methods are a convenient way for deciphering the chemical composition of fossil tissues (i.e. Stankiewicz et al., 1997a). Unfortunately, the small size of chitinozoans (typically $100 \mu \mathrm{m}$ to $200 \mu \mathrm{m}$ ) prevents the use of conventional analytical methods. The laser micropyrolysis-gas chromatography/mass spectrometry (LmPyGC/MS) method is ideally suited to the analysis of microfossils and other very small samples of organic matter (Greenwood et al., 1996, 1998) and has been successfully 
applied to Tasmanites kerogen, solid bitumens and acritarchs (Arouri et al., 1999; Greenwood et al., 2000, 2001). In this study LmPy-GC/MS was performed on individual specimens of exceptionally well-preserved chitinozoans, and the results are compared with micro-elemental analysis, micro-Fourier Transform Infrared (microFTIR) spectroscopy and laser micro-Raman spectroscopy on individually picked chitinozoans.

\section{Materials and methods}

Samples Q134.2 and Q136.5 consist of greenish shale and were collected at depths of $134.2 \mathrm{ft}$ and $136.5 \mathrm{ft}$, respectively, from the Qusaiba Member of the Qalibah Formation (lower Silurian, Monograptus convolutus Zone) penetrated by the Qusaiba 1 shallow borehole, Qasim area north-northwest of the deserted Qusaiba village, Saudi Arabia (see Zalasiewicz et al., in press). This borehole was drilled to obtain unweathered samples for palynology and also a continuous stratigraphic record of the Qusaiba Member for sedimentological study. The stratigraphic terminology applied to the Silurian section in this area was summarized by Manivit et al. (1985) and modified by Mahmoud et al. (1992).

The chitinozoans were extracted from shale using the technique described by Paris (1981). The core samples were first fragmented and crushed in a mortar. Twenty grams of the $0.80-1.40 \mathrm{~mm}$ size fraction were treated for two hours in $\mathrm{HCl}$, followed by 48 hours in HF. After several neutralizing washes, the remaining organic residue was sieved. The chitinozoans were picked using a micropipette from the $>53 \mu \mathrm{m}$ fraction of the organic residue. The selected individuals were washed five times in distilled water. All the small amorphous organic particles were carefully removed during these 
washings. No oxidative agents were used during the processing so as to prevent modification of the chemical composition of the chitinozoan vesicle walls. The specimens selected for the elemental microanalyses were ultrasonicated for 30 seconds in order to remove the framboidal pyrite trapped within some vesicles.

About 1100 Cyathochitina specimens were extracted by this means from sample Q134.2 (for laser micropyrolysis-GC/MS, laser micro-Raman and micro-FTIR analyses). About 10500 specimens of mixed chitinozoan genera representatives of Cyathochitina (40\%), Angochitina (13\%) and Calpichitina (43\%) were isolated from sample Q136.5 (for elemental microanalyses).

Rock-Eval pyrolysis was performed on $60 \mathrm{mg}$ of bulk powdered rock of sample Q134.2 using standard techniques (Lafargue et al., 1998). Three elemental (C, H, N and S) microanalyses runs were performed, each on about 3000 chitinozoan specimens isolated from sample Q136.5, weighing $300 \mu \mathrm{g}$. Micro-FTIR spectra were recorded on individual Cyathochitina specimens from sample Q134.2 in the $4000-650 \mathrm{~cm}^{-1}$ range with a spectral resolution of $4 \mathrm{~cm}^{-1}$ using a FT-IR Magna-IR 760 spectrometer equipped with a Nicolet Nic-Plan IR microscope fitted with a mercury-cadmium-telluride (MCT) detector. The analysed sample area was a $100 \mu \mathrm{m}$ diameter circle. Laser micro-Raman data were acquired on individual specimens of Cyathochitina sp. from sample Q134.2 using a Dilor XY800 spectrometer equipped with a Coherent argon laser (Innova 90-5) and coupled to an Olympus microscope. The analysed sample area size was about the excitation laser wavelength $(0.5 \mu \mathrm{m})$.

The LmPy-GC/MS instrument used was the same one as described by Greenwood et al. (1998), but with some modifications. It comprised a Hewlett Packard 6890 Gas Chromatograph (GC) interfaced to both a Hewlett Packard 5973 Mass 
Selective Detector (electron energy $70 \mathrm{eV}$, electron multiplier $1200 \mathrm{~V}$, source temperature $250^{\circ} \mathrm{C}, 0.1 \mathrm{amu}$ resolution) and an Olympus $\mathrm{BX} 60 \mathrm{M}$ system microscope with a custom-built laser chamber and inlet system. The microscope was used with long working distance objectives $(10 \mathrm{x}, 0.25, \infty /-\mathrm{f}=180)$ and a Laser Applications 55W continuous wave Nd-YAG infrared (IR) laser at 1,064 nm. Chitinozoans of the genus Cyathochitina isolated from sample Q134.2 were deposited on a glass slide that was then placed in the laser chamber. About 30 chitinozoan specimens were analysed in each analytical run. Several runs were carried out so as to optimize experimental conditions and test reproducibility. A blank analys is and an analysis consisting of firing the laser on the glass slide between the chitinozoan targets were performed in order to check for system contaminants. The sample chamber was held at $110^{\circ} \mathrm{C}$, helium was used as the sweep gas ( 5 psi head pressure) and a flow of $100 \mathrm{~mL} / \mathrm{min}$ was maintained throughout the laser pyrolysis. Chromatography was carried out on a $\mathrm{J} \& \mathrm{~W}$ fused silica column (25 m x $0.32 \mathrm{~mm}$ i.d.) coated with DB5 phase (5\% phenyl 95\% methyl silicone, $0.52 \mu \mathrm{m}$ film thickness). Pyrolysates liberated from the pyrolysis chamber after each run were cryogenically trapped in a coiled nickel loop using a liquid nitrogen bath. After trapping, a 6-port Valco valve was rotated to transfer the $1 \mathrm{~mL} / \mathrm{min}$ column helium flow through the nickel trap. The contents of the nickel trap were then desorbed by heating to $320^{\circ} \mathrm{C}$ and the products were cryo-focused in a loop of the GC column immersed in a liquid nitrogen bath. After 10 min the cryogenic trap was removed and acquisition commenced. The GC oven was programmed from an initial temperature of $20^{\circ} \mathrm{C}(5 \mathrm{~min}$. hold $)$ at $10^{\circ} \mathrm{C} \mathrm{min} .{ }^{-1}$ to $40^{\circ} \mathrm{C}$, then at $4^{\circ} \mathrm{C} \mathrm{min} .{ }^{-1}$ to $320^{\circ} \mathrm{C}$, which was held for 19 mins. Pyrolysis products were analysed using a quadrupole scanning programme of $m / z$ 20-75 Dalton (Da) for 2 min to detect gases and $m / z 50-550 \mathrm{Da}$ for the 
remainder. Peak identities were determined by comparison of spectra with the NIST 98 library.

\section{Results}

\subsection{Rock-Eval pyrolysis}

Total Organic Carbon (TOC) is $0.47 \%$, the Hydrogen Index (HI) is $157 \mathrm{mg}$ HC. $\mathrm{g}^{-1}$ TOC, the Oxygen Index (OIRE6) is $44 \mathrm{mg} \mathrm{O}_{2} \cdot \mathrm{g}^{-1} \mathrm{TOC}$ and the $\mathrm{T}_{\max }$ is $420^{\circ} \mathrm{C}$.

\subsection{Elemental microanalysis}

The elemental microanalysis performed on a mixed sample consisting of Angochitina, Calpichitina and Cyathochitina specimens (the latter having the greatest contribution because of their abundance and much larger vesicle size) gave the following results: 60 (weight $\%$ ) carbon, $4 \%$ hydrogen, $3 \%$ nitro gen and ca. $4 \%$ sulphur, the remaining being possibly oxygen. This gives an atomic $\mathrm{H} / \mathrm{C}$ of 0.8 . Sulphur comes from pyrite crystals remaining inside the chitinozoan vesicles.

\subsection{Micro-FTIR}

The Micro-FTIR spectrum obtained from an individual Cyathochitina specimen isolated from sample Q136.5 shows peaks in the $2860-2960 \mathrm{~cm}^{-1}$ region (centred at 2960, 2930 and $2865 \mathrm{~cm}^{-1}$ ) that reflect the asymmetric and symmetric stretching of alkyl $\mathrm{CH}_{2}$ groups (Fig. 1). The band at $1450 \mathrm{~cm}^{-1}$ is due to asymmetric bending of $\mathrm{CH}_{2}$ and $\mathrm{CH}_{3}$ groups and the peak at $1360 \mathrm{~cm}^{-1}$ is attributed to symmetric bending of $\mathrm{CH}_{3}$ groups. Aromatic groups are also abundant as shown by the large peak centred at 1610 $\mathrm{cm}^{-1}$ that arise from the $\mathrm{C}=\mathrm{C}$ stretching of olefins, aromatic rings and polyaromatic 
layers. The broad and unresolved band between 700 and $850 \mathrm{~cm}^{-1}$ is attributed to the plane deformation vibrations of aromatic $\mathrm{CH}$ groups. Oxygenated functions are responsible for the shoulder near $1710 \mathrm{~cm}^{-1}$ that results from $\mathrm{C}=\mathrm{O}$ stretching of carbonyl and carboxyl groups, whilst the peak at $1060 \mathrm{~cm}^{-1}$ indicates C-O-C bonds. The hydroxyl stretching group is responsible for the broad band ranging between 3100 and $3700 \mathrm{~cm}^{-1}$ and centred around $3400 \mathrm{~cm}^{-1}$, although a contribution from $\mathrm{NH}$ bonds and adsorbed water cannot be excluded. The extension of this broad band towards lower values could be attributable to carboxylic acids. The presence of $\mathrm{NH}$ bonds may be responsible of a shoulder at $1550 \mathrm{~cm}^{-1}$.

\subsection{Laser micro-Raman spectroscopy}

The laser micro-Raman spectrum obtained from Cyathochitina specimens of sample Q134.2 (Fig. 2) produced a significant peak centred at $\sim 1600 \mathrm{~cm}^{-1}$ and a broad, less intense, band centred at $\sim 1350 \mathrm{~cm}^{-1}$. This spectrum displays similar features for chitinozoans to that obtained by Roberts et al. (1995). The major peak at $1600 \mathrm{~cm}^{-1}$ is attributed to ordered $\mathrm{C}=\mathrm{C}$ stretching within graphite layers and the less intense peak at

$\sim 1355 \mathrm{~cm}^{-1}$ is attributed to minimal vibrations from disordered carbon structures. The line-width of the peak centred at $1600 \mathrm{~cm}^{-1}$ is $\sim 110 \mathrm{~cm}^{-1}$, approaching the value found for low rank chitinozoan specimen s by Roberts et al. (1995).

\section{5. $L m P y-G C / M S$}

Representative chromatograms obtained by LmPy-GC/MS of Cyathochitina specimens from sample Q134.2 are illustrated in Fig. 3. The total ion chromatogram is dominated by aromatic hydrocarbons, including benzene, toluene, ethylbenzene, m-, p- 
and o-xylenes, phenylethyne, styrene, indene, methylindene, naphthalene, methylnaphthalenes and biphenylene. 1,3-butadiene and carbon disulphide are also abundant. The added $\mathrm{m} / \mathrm{z} 57+71+85$ mass chromatogram shows that low levels of $\mathrm{C}_{10}$ to $\mathrm{C}_{16} n$-alkanes are present, but a proportion of the higher molecular weight $n$-alkanes $($ marked by $*)$ are system contaminants, as demonstrated by system blanks. The high abundance of $n-\mathrm{C}_{24}$ alkane is apparently a genuine feature of the pyrolysates of these chitinozoans. Trace compounds of interest include phenol and methylphenols $(\mathrm{m} / \mathrm{z}$ 94+107), and benzonitrile and benzylnitrile $(\mathrm{m} / \mathrm{z} 117+103)$.

\section{Dis cussion}

The $\mathrm{T}_{\max }$ value of $420{ }^{\circ} \mathrm{C}$ indicates that the rock sample is thermally immature and is in agreement with the micro-Raman data. The LmPy-GC/MS results are in good agreement with the infrared spectroscopy and elemental microanalysis. The low $\mathrm{H} / \mathrm{C}$ ratio is consistent with highly aromatic organic matter, and this is also demonstrated by the numerous aromatic compounds detected by LmPy-GC/MS, and with the prominent IR bands that show aromatic structures. The few oxygenated compounds such as phenol and methylphenol that were detected by LmPy-GC/MS can be related to the bands at $1710 \mathrm{~cm}^{-1}, 1060 \mathrm{~cm}^{-1}$ and the one centred around $3400 \mathrm{~cm}^{-1}$ in the IR spectrum. The nitrogen-containing compounds that were detected by LmPy-GC/MS could be related to the shoulder at $1550 \mathrm{~cm}^{-1}$. The major discrepancy between the micro-FTIR and LmPyGC/MS results lies in the abundance of aliphatic compounds. Several bands in the micro-FTIR spectra attest to a significant contribution of aliphatic compounds to the organic structure of chitinozoans (Fig. 2). If $n$-alkanes identified as system contaminants are excluded, the distribution of $n$-alkanes on the chitinozoan pyrogram is very limited 
in abundance, although the moderate abundance of $n-\mathrm{C}_{24}$ is notable though so far unexplained. The macromolecular structure of chitinozoans can thus be viewed as kerogen dominated by a network of aromatic compounds, linked by short $n$-alkyl chains. No pyrolysis products diagnostic for the presence of chitin, such as acetamide, acetamidofurans, acetamidopyrone, oxazoline and pyridone derivatives (Baas et al., 1995; Stankiewicz et al., 1997a, 1997b, 1998a), was detected in the pyrogram of the chitinozoans.

The diagenesis of fossil cuticles has been intensively studied (Baas et al., 1995, Stankiewicz et al., 1997a, 1997b, 1998a, 1998b), allowing some comparisons. According to Stankiewicz et al. (1997a), fossil cuticles can be distinguished as either aliphatic or aromatic by analytical pyrolysis. The low abundance of $n$-alkyl lipids in the pyrolysate of chitinozoans could indicate that any incorporation or in-situ polymerisation of aliphatic moieties from other materials did not occur during diagenesis (Stankiewicz et al., 1997a). The absence of sulphur-containing compounds, except for carbon disulphide, excludes the possibility of inorganic sulphur incorporation under anoxic conditions. Alkylated indenes, proposed by Stankiewicz et al. (1997a) as markers of fossil invertebrate cuticles, were not detected in our samples. When compared to other fossils, highly aromatic signatures have been found in squids and decapod shrimps (Stankiewicz et al., 1997a), whereas eurypterids, scorpions, water bugs, acritarchs, Tasmanites kerogen and graptolites are characterized by pyrograms dominated by aliphatic compounds (Stankiewicz et al., 1997a; Arouri et al., 1999; Greenwood et al., 2000; Gupta et al., 2006). Unfortunately, this sole criterion does not provide insight into chitinozoan biological affin ities. 


\section{Conclusions}

Laser pyrolysis GC/MS performed on ind ividual and well-preserved chitinozo an specimens extracted from Silurian marine rocks revealed no direct evidence for the preservation of chitin-related compounds. The organ ic structure of chitinozoans appears to be a kerogen network dominated by aromatic units with few aliphatics. These results could be due to: (1) the loss of chitin or related compounds during diagenesis; (2) the loss of chitin during sample preparation and extraction from the host rock; or (3) the absence of chitin in the initial material. The former point is consistent with previous observations on the early decay of chitin in fossil specimen s (Stankiewicz et al., 1997a). Further work performed on materials subjected to milder isolation treatments will examine whether sample preparation and extraction from the host rock can remove chitin.

\section{Acknowledgements}

The authors thank Saudi Arabian Ministry of Petroleum and Mineral Resources and the Saudi Arabian Oil Company (Saudi Aramco) for providing shallow core samples and for granting permission to publish the results. They also thank Cameron McIntyre and David Fuentes for help with the laser micropyrolysis-GC/MS at CSIRO (Australia), and Muriel Escadeillas who carried out the element microanalyses at CRMPO (University of Rennes 1, France). This research is supported by the ECLIPSE program (INSUCNRS, France). The reviewers are acknowledged for improving the manuscript. 


\section{References}

Arouri, K.R., Greenwood, P.F., Walter, M.R., 1999. A possible chlorophycean affinity of some Neoprotero zoic acritarchs. Organic Geochemistry 30, 1323-1337.

Baas, M., Briggs, D.E.G., Van Heemst, J.D.H., Kear, A.J., De Leeuw, J.W., 1995. Selective preservation of chitin during the decay of shrimp. Geochimica et Cosmochimica Acta 59, 945-951.

Brumioul, D., Voss-Foucart, M.F., 1977. Substances organiques dans les carapaces de crustacés fossiles. Comparative Biochemistry and Physiology 57, 171-175.

Eisenack, A. 1931. Neue Mikrofossilien des baltischen Silurs I. Palaeontologische Zeitschrift 13, 74-118.

Greenwood, P.F., George, S.C., Wilson, M.A., Hall, K.J., 1996. A new apparatus for laser micropyrolysis-gas chromatography/mass spectrometry. Journal of Analytical and Applied Pyrolysis 38, 101-118.

Greenwood, P.F., George, S.C., Hall, K., 1998. Application s of laser micropyrolysis-gas chromatography-mass spectrometry. Organic Geochemistry 29, 1075-1089.

Greenwood, P.F., Arouri, K.R., George, S.C., 2000. Tricyclic terpenoid composition of Tasmanites kerogen as determined by pyrolysis GC-MS. Geochimica et Cosmochimica Acta 64, 1249-1263.

Greenwood, P.F., George, S.C., Pickel, W., Zhu, Y., Zhong, N., 2001. In situ analytical pyrolysis of coal macerals and solid bitumens by laser micropyrolysis GC-MS. Journal of Analytical and Applied Pyrolysis 58-59, 237-253.

Gupta, N.S., Briggs, D.E., Pancost, R.D., 2006. Molecular taphonomy of graptolites. Journal of the Geological Society, London, 163, 897-900. 
Lafargue, E., Espitalié, J., Marquis, F., Pillot, D., 1998. Rock-Eval 6 applications in hydrocarbon exploration, production, and in soil contamination studies. Revue de l'Ins titut Français du Pétrole 53, 421-437.

Mahmoud, M.D., Vaslet, D., Husseini, M.I., 1992. The Lower Silurian Qalibah Formation of Saudi Arabia: an important hydrocarbon source rock. The American Association of Petroleum Geologists, Bulletin 76, 1491-1506.

Manivit, J., Vaslet, D., Berthiaux, A., Le Strat, P., Fourniguet, J., 1985. Explanatory notes to the geological map of the Buraydah Quadrangle, Kingdom of Saudi Arabia. Geoscience Map GM-114C, scale 1:250,000, sheet 26 G. Ministry of Petroleum and Mineral Resources, Deputy Ministry for Mineral Resources, $32 \mathrm{p}$.

Miller, M.A., 1996. Chitinozoa. In: J. Jansonius and D.C. McGregor (Eds), Palynology: principles and applications. American Association of Stratigraphic Palynologists Foundation. Dallas, 1, pp. 307-336.

Paris, F., 1981. Les chitinozoaires dans le Paléozoïque du sud-ouest de l'Europe (Cadre géologique -Etude systématique - Biostratigraphie). Mémoire de la Société géologique et minéralogique de Bretagne 26, pp. 1-496.

Paris, F., 1996. Chitinozoan biostratigraphy and Paleogeography. In: J. Jansonius and D.C. McGregor (Eds), Palynology: principles and applications. American Association of Stratigraphic Palynologists Found ation, Dallas, 2, pp. 531-552.

Paris, F., Nõlvak, J., 1999. Biological interpretation and paleobiodiversity of a cryptic fossil group: the "chitinozoan-animal". Geobios 32, 315-324.

Paris, F., Grahn, Y., Nestor, V., Lakova, I., 1999. A revised chitinozoan classification. Journal of Paleontology 73, 549-570. 
Roberts, S., Tricker, P.M., Marshall, J.E.A., 1995. Raman spectroscopy of chitinozoans as a maturation indicator. Organic Geochemistry 23, 223-228.

Stankiewicz, B.A., Briggs, D.E.G., Evershed, R. P., 1997a. Chemical composition of Paleozoic and Mesozoic fossil invertebrate cuticles as revealed by pyrolysis-gas chromatography/mass spectrometry. Energy \& Fuels, 11, 515-521.

Stankiewicz, B.A., Briggs, D.E.G., Evershed, R.P., Flannery, M.B., Wuttke, M., 1997 b. Preservation of chitin in 25-million-year-old fossils. Science, 276, 1541-1543.

Stankiewicz, B.A., Mastalerz, M., Hof, C.H.J., Bierstedt, A., Flannery, M., Briggs, D.E.G., Evershed, R.P., 1998a. Biodegradation of the chitin-protein complex in crustacean cuticles. Organic Geochemistry 28, 67-76.

Stankiewicz, B.A., Scott, A.C., Collinson, M.E., Finch, P., Mösle, B., Briggs, D.E.G., Evershed, R.P., 1998b. Molecular taphonomy of arthropod and plant cuticles from the Carboniferous of North America: implications for the origin of kerogen. Journal of the Geological Society, London 155, 453-462.

Voss-Foucart, M.F., Jeuniaux, C., 1972. Lack of chitin in a sample of Ordovician chitinozoa. Journal of Paleontology 46, 769-770.

Zalasiewicz, J., Williams, M., Miller, M.A., Page, A., Blackett, E., in press. Early Silurian (Llandovery) graptolites from central Saudi Arabia: first documented record of Telychian faunas from the Arabian Peninsula. Geo Arabia.

\section{Figure captions}

Figure 1: Absorption micro-FTIR spectra of chitinozoans in the region $650-3800 \mathrm{~cm}^{-1}$ for representatives of Cyathochitina sp. Assignments of absorption bands and vibration 
modes $(\delta=$ deformation; $v=$ stretching; $s=$ symmetric; as=asymmetric $)$ were made according to Arouri et al. (1999).

Figure 2: Laser Raman microprobe spectrum of a Cyathochitina sp. specimen.

Figure 3: LmPy-GC/MS data for specimens of Cyathochitina sp., showing total ion chromato gram (TIC), added $\mathrm{m} / \mathrm{z} 57+71+85$ mass chromatogram for alkanes, added $\mathrm{m} / \mathrm{z}$ 94+107 mass chromatogram for phenols and added $\mathrm{m} / \mathrm{z}$ 103+117 mass chromatogram for benzonitrile and benzylnitrile. 
Figure(s)

Figure 1

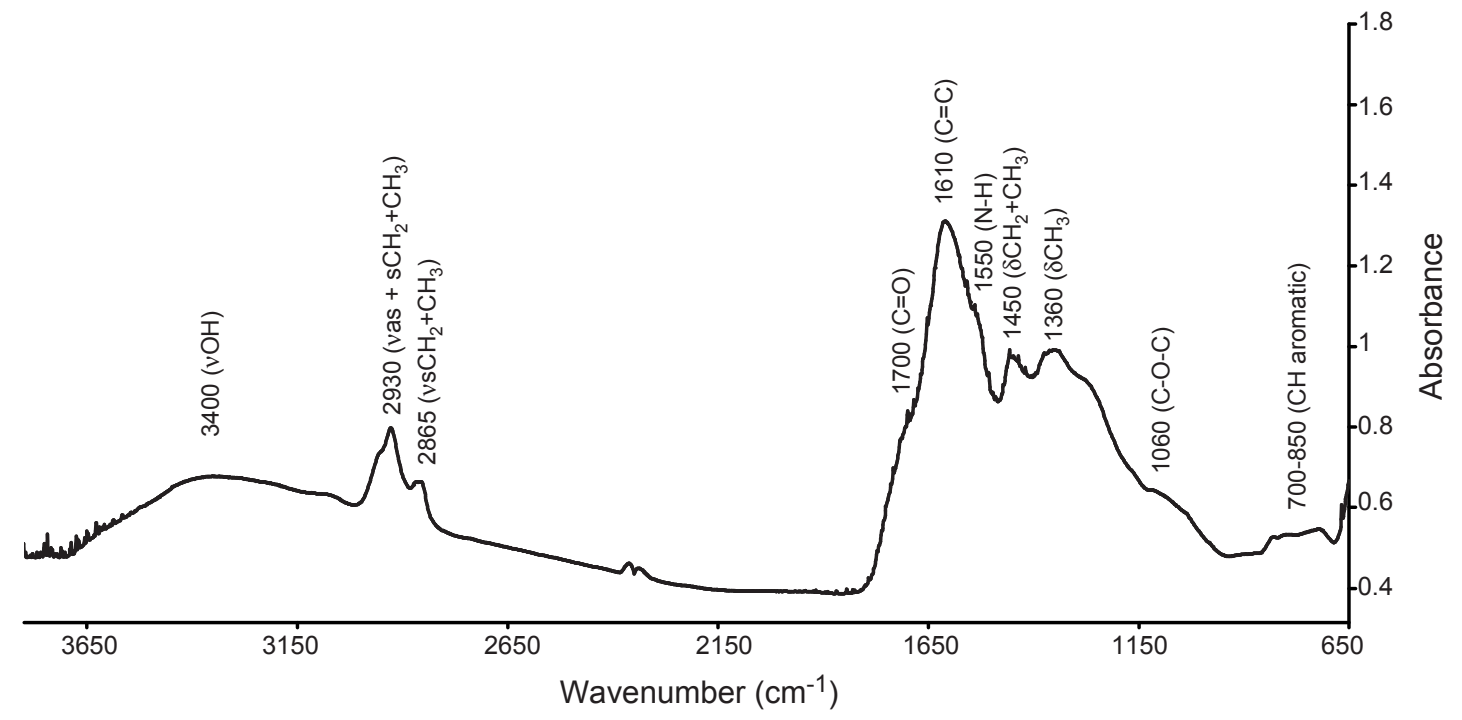


Figure 2

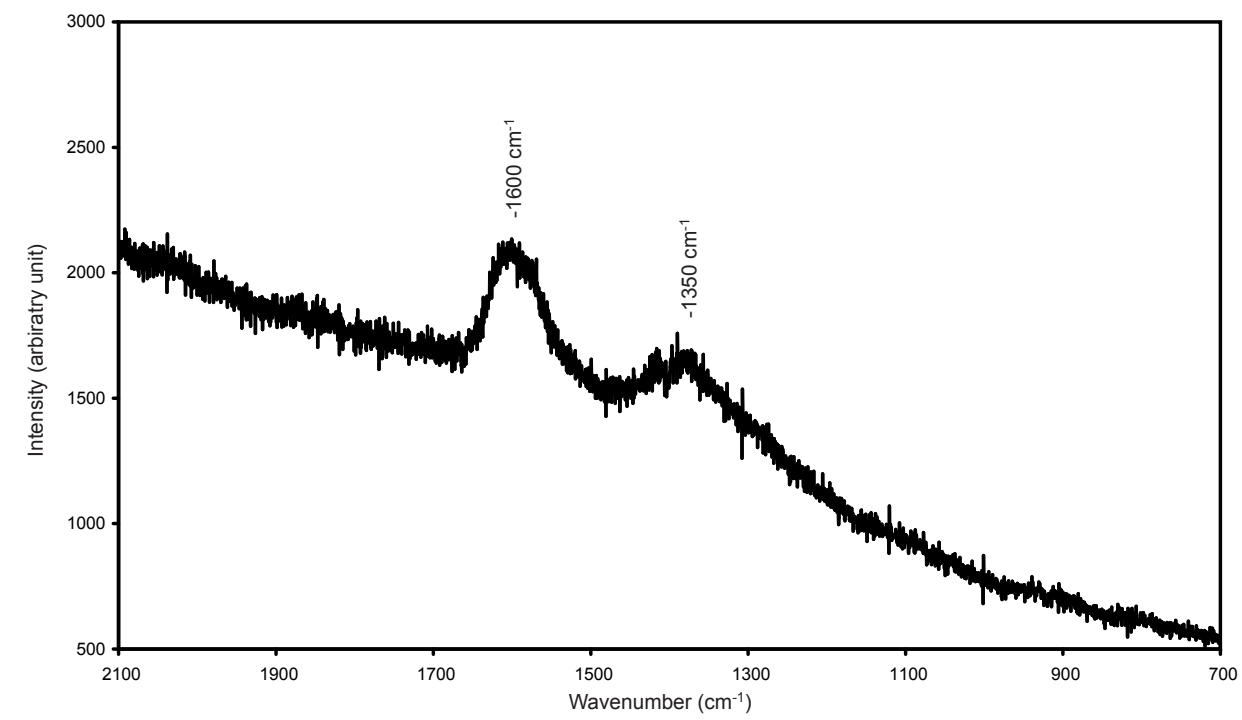

Figure(s) 
Figure 3
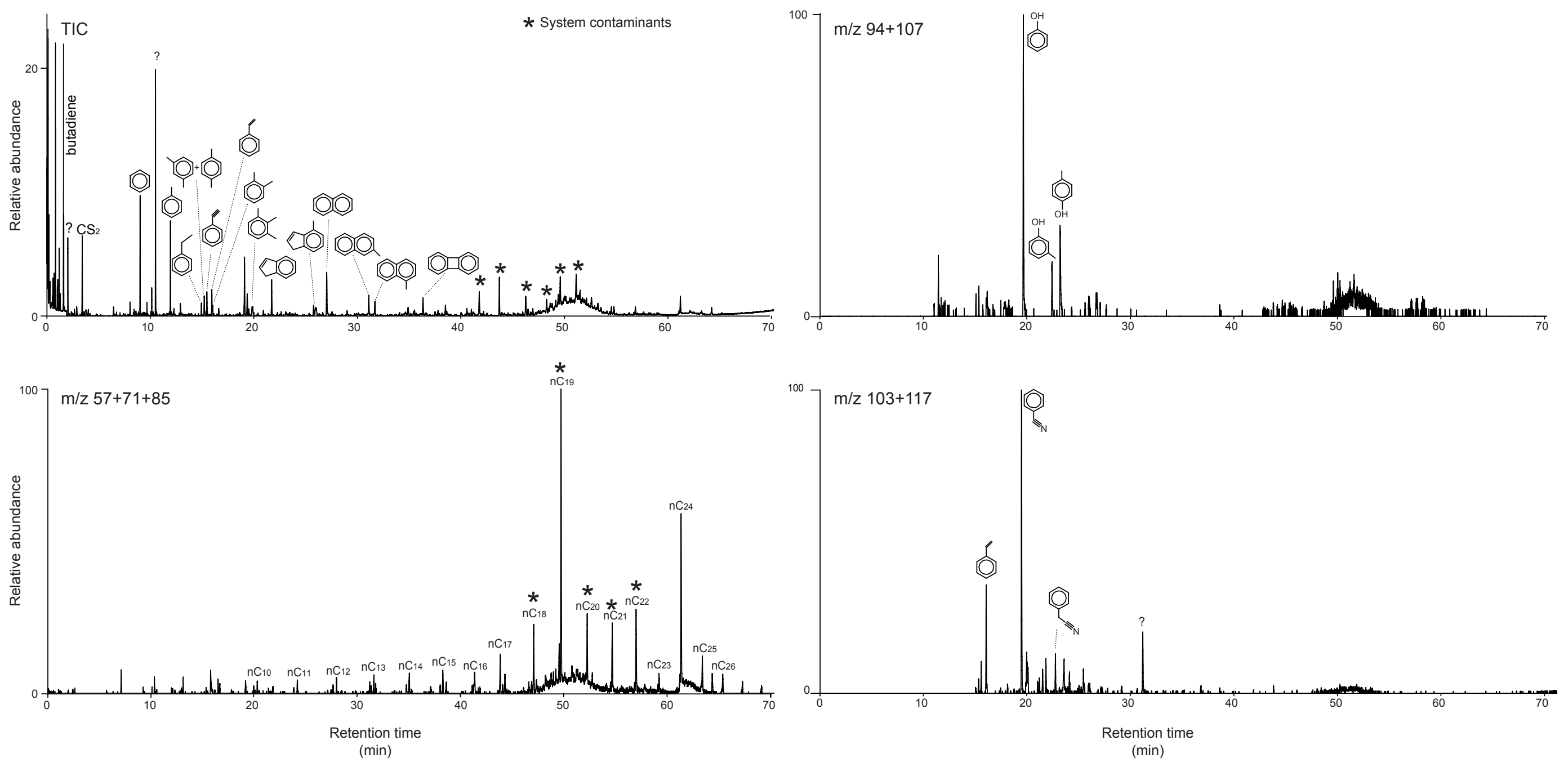